Helena KARCZEWSKA*

\title{
WIARA W ŻYCIU CZLOWIEKA W UJĘCIU ŚW. HILAREGO Z POITIERS
}

Wiara - źródło i fundament życia duchowego człowieka - to jedno z głównych zagadnień obecnych w Hilariańskich dziełach. Nie bez powodu Biskup skupia się na ukazaniu jej roli w codzienności wierzącego. Przede wszystkim jako obrońca wiary ortodoksyjnej Biskup z Poitiers czynnie brał udział $\mathrm{w}$ walce $\mathrm{z}$ rozszerzającym się $\mathrm{w}$ jego czasach arianizmem. Jego nauczanie, łączące alegorię z wykładnią prawd wiary, skupia się na ukazaniu bóstwa Jezusa Chrystusa ${ }^{1}$. Nie można odmówić Biskupowi starania i troski o właściwe poznanie ortodoksyjnego nauczania Kościoła. Ważny jest dla niego rozwój zarówno intelektualny, jak i duchowy wierzącego. Jednak aby człowiek mógł zrozumieć i posiąść wiedzę na temat Boga, potrzeba mu jest wiara. Jest ona ważna przede wszystkim w osobistym życiu wierzącego, ale też stanowi główną rolę w zwalczaniu herezji. W nauczaniu Hilarego wiara to główny oręż w walce duchowej człowieka, dar, dzięki któremu istota ludzka może osiągnąc zbawienie. W dobie kryzysu ariańskiego Biskup z Poitiers uznał za konieczne uzbrojenie wierzących przeciwko arianom oraz pouczania zarówno wiernych mniej oświeconych (simpliciores), jak i początkujących na drodze wiary².

Analizując dzieła Biskupa z Poitiers - zwłaszcza Komentarz do Ewangelii św. Mateusza $a^{3}$ i Traktat na temat Psalmó $w^{4}$ - w kontekście wiary w życiu człowieka, należy skupić się na czterech istotnych zagadnieniach. Jako pierwsza zostanie omówiona Hilariańska definicja wiary i kryteria umożliwiające uzna-

* Dr Helena Karczewska - adiunkt w Katedrze Historii Kościoła w Starożytności i w Średniowieczu w Instytucie Nauk Historycznych na Wydziale Nauk Historycznych i Społecznych Uniwersytetu Kard. Stefana Wyszyńskiego w Warszawie; e-mail: h.karczewska@uksw.edu.pl.

${ }^{1}$ Ważnym w poznaniu antyariańskiej działalności Hilarego jest jego dzieło O Trójcy Świętej. Por. Hilarius Pictaviensis, De Trinitate, ed. P. Smulders, CCL 62 i 62A, Turnhout 1979-1980, thum. E. Stanula: Św. Hilary z Poitiers, O Trójcy Świętej, PSP 64, Warszawa 2005.

${ }^{2}$ Por. M. Fiedrowicz, Teologia ojców Kościoła. Podstawy wczesnochrześcijańskiej refleksji nad wiarq, tłum. W. Szymona, Kraków 2009, 44.

${ }^{3}$ Por. Hilarius Pictaviensis, Commentarius in Matthaeum, ed. J. Doignon, SCh 254 i 258, Paris 1978-1979, thum. E. Stanula: Św. Hilary z Poitiers, Komentarz do Ewangelii św. Mateusza, PSP 63, Warszawa 2002, 43-200.

${ }^{4}$ Por. tenże, Tractatus super Psalmos, ed. A. Zingerle, CSEL 22, Vindobonae 1891. Traktat na temat Psalmów do tej pory nie doczekał się polskiego przekładu. Wszystkie cytowane fragmenty tego dzieła zostały przetłumaczone przez autorkę na potrzeby tego artykułu. 
nie jej za prawdziwą, następnie będzie poruszone zagadnienie wiary w walce $\mathrm{z}$ herezją. Próba wiary i uczynki z niej wynikające to kolejny $\mathrm{z}$ omawianych aspektów nauczania Biskupa. Warto podkreślić, że są to jedne z ważniejszych zagadnień dotyczących wiary człowieka, jednak nie wszystkie, które można znaleźć w dziełach Biskupa.

1. Definicja wiary. Poruszając temat wiary w życiu człowieka, należy rozpoczać od postawienia pytania, jak Biskup z Poitiers rozumie wiarę i jaka jej definicję podaje. Według Hilarego wiara jest właściwym pojmowaniem Boga Ojca i Jezusa Chrystusa ${ }^{5}$, i rozumieniem jedności Trójcy Swiętej ${ }^{6}$. Jak zauważa „uwierzyć w Chrystusa stanowi istotę wiary” , o jej zaś doskonałości może świadczyć przekonanie, że Syn Boży przyjął ludzką naturę i stał się człowiekiem $^{8}$. Przez wiarę serce otwiera się na tajemnicę Ojca i Syna i Ducha Świętego, a odkąd jest ono otwarte, wierzący może biec po Bożej drodze ${ }^{9}$. Hilary tworzy definicję wiary, która ma początek $\mathrm{w}$ woli ${ }^{10}$. Przeciwstawia niezdecydowanej i chwiejnej woli pewność wiary ${ }^{11}$, przez którą Bóg pociaga człowieka do siebie ${ }^{12}$. Wyraźnie widać, że definicja wiary jest zarówno odpowiedzią na wątpliwości wiernych dotyczących właściwego pojmowania Boga, jak i elementem apologetycznym w twórczości Hilarego ${ }^{13}$. Wiara zatem w nauczaniu Biskupa to przede wszystkim uznanie bóstwa Jezusa ${ }^{14}$.

W Hilariańskich dziełach spotykamy często stwierdzenia, że nie każdą wiarę można uznać za prawdziwą. Aby wierzący nie mieli wątpliwości, podaje pewne kryteria. Są to określenia, które Hilary stosuje w nauczaniu o wierze dla odróżnienia, co jest właściwe dla prawdziwego chrześcijanina, a co dla człowieka chwiejnego, oddanego herezji i mocy diabła. Wiara, zdaniem Biskupa, powinna być przede wszystkim niestrudzona (indefess $a)^{15}$ i niezłomna (perseverans) ${ }^{16}$, nieprzemijająca (non temporaria $)^{17}$, niewzruszona i niechwiejna (inmobilis) ${ }^{18}$, niezmienna (indemutata) ${ }^{19}$

${ }^{5}$ Por. tenże, Tractatus super Ps.118 aleph 12, CSEL 22, 366-367.

${ }^{6}$ Por. tenże, Commentarius in Matthaeum XIII 6, SCh 254, 300, PSP 63, 115.

${ }^{7}$ Por. tenże, De Trinitate VI 41, CCL 62, 245-246, PSP 64, 193; tamże IV 42, CCL 62, 147-148, PSP 64, 194.

${ }^{8}$ Por. tenże, Commentarius in Matthaeum XVI 5, SCh 258, 52, PSP 63, 129.

${ }^{9}$ Por. tenże, Tractatus super Ps. 118 daleth 12, CSEL 22, 397-398.

${ }^{10}$ Por. E. Stanula, Czynniki kształtujace sens biblijny w ujęciu św. Hilarego z Poitiers, SACh 4 (1984) 146.

${ }^{11}$ Por. Hilarius Pictaviensis, Commentarius in Matthaeum VI 2, SCh 254, 172, PSP 63, $72-73$.

${ }^{12}$ Por. tenże, De Trinitate XI 33, CCL 62A, 561-562, PSP 64, 378.

${ }^{13}$ Por. Fiedrowicz, Teologia ojców Kościoła, s. 44.

${ }^{14}$ Por. Hilarius Pictaviensis, Tractatus super Ps. 124, 7, CSEL 22, 602-603.

${ }^{15}$ Por. tamże 118 zade 1, CSEL 22, 515.

${ }^{16}$ Por. tamże.

${ }^{17}$ Por. tamże 122, 8, CSEL 22, 585.

${ }^{18}$ Por. tamże.

${ }^{19}$ Por. tamże. 
oraz wytrwała (constans) ${ }^{20}$, pewna i wypróbowana (vera fidei probatio ${ }^{21}$, certa fides ${ }^{22}$ ). Określenia te wyrażają pewną stałość wiary (constans fides ${ }^{23}, f$ dei firmitas ${ }^{24}$ ). Wskazują one, jaką postawę powinien przyjmować wierzący w swojej codzienności. Są to cechy godne prawdziwego chrześcijanina, wiernego Bogu i Jego słowom. Niezłomność i wytrwałość oraz pewność i ufność w Boże obietnice mają zapewnić mu największą nagrodę - zbawienie ${ }^{25}$. Hilary uważa również, że wiara musi być zarówno doskonała (perfecta ${ }^{26}$, consummata fides $^{27}$ ) i prawdziwa (veritas fide ${ }^{28}$, fides vera $^{29}$ ), jak też prosta (simplicitas fidei $)^{30}$, aby różniła się od wiary heretyków i pogan. Dodaje także inne określenia charakteryzujące wiarę. Powinna ona być żarliwa (aestus fidei ${ }^{31}$, calor fidei $^{32}$, ardor spiritus ${ }^{33}$ ) i pobożna ( pia $^{34}$, pietas fidei $i^{35}$ ), żywa, podlegająca rozwojowi i pomnażaniu (incrementum fidei $)^{36}$ oraz pokorna (modesta) $)^{37}$ i szczera

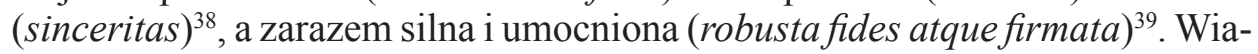
ra powinna być związana z Bożym Objawieniem i nauczaniem Kościoła (fides catholica) $)^{40}$, a więc ewangeliczna (fides evangelica) ${ }^{41}$ i apostolska (apostolica

${ }^{20}$ Por. tamże 52, 12, CSEL 22, 125-126; tamże 118 gimel 20, CSEL 22, 389-390; tenże, De Trinitate X 51, CCL 62A, 504-505, PSP 64, 345-346.

${ }^{21}$ Por. tenże, Tractatus super Ps. 128, 5, CSEL 22, 640-641.

${ }^{22}$ Por. tenże, Commentarius in Matthaeum XXVI 3, SCh 258, 196, PSP 63, 176.

${ }^{23}$ Por. tenże, Tractatus super Ps. 52, 12, CSEL 22, 125-126; tamże 118 gimel 20, CSEL 22, 389-390.

${ }^{24}$ Por. tamże 59, 6, CSEL 22, 196-198.

${ }^{25}$ Por. tenże, Commentarius in Matthaeum IX 9, SCh 254, 212-214, PSP 63, 87; tamże X 13, SCh 254, 231, PSP 63, 92; tamże XXI 7, SCh 258, 130-132, PSP 63, 155.

${ }^{26}$ Por. tenże, De Trinitate I 26, CCL 62, 23-24, PSP 64, 71-72; tenże, Tractatus super Ps. 118 mem 13, CSEL 22, 473-474; tenże, Commentarius in Matthaeum VI 2, SCh 254, 172, PSP 63, 72 73; tamże X 13, SCh 254, 230-232, PSP 63, 92-93.

${ }^{27}$ Por. tenże, Tractatus super Ps. 132, 4, CSEL 22, 686.

${ }^{28}$ Por. tamże 118 alpeh 12, CSEL 22, 366-367.

${ }^{29}$ Por. tenże, De Trinitate IX 3, CCL 62A, 373-374, PSP 64, 269; tenże, Tractatus super Ps. 67, 16, CSEL 22, 291.

${ }^{30}$ Por. tenże, Tractatus super Ps. 118 lamed 15, CSEL 22, 466; tenże, Commentarius in Matthaeum IV 23, SCh 254, 142, PSP 63, 62.

${ }^{31}$ Por. tenże, De Trinitate VII 1, CCL 62, 259, PSP 64, 201.

${ }^{32}$ Por. tenże, Tractatus super Ps. 134, 27, CSEL 22, 711-712.

${ }^{33}$ Por. tamże 2, 46, CSEL 22, 72-73.

${ }^{34}$ Por. tenże, De Trinitate V 31, CCL 62, 183-184, PSP 64, 161-162; tamże IX 43, CCL 62A, 419-420, PSP 64, 295-296.

${ }^{35}$ Por. tamże IX 47, CCL 62A, 424-425, PSP 64, 298-299.

${ }^{36}$ Por. tenże, Tractatus super Ps. 118 nun 14, CSEL 22, 483.

${ }^{37}$ Por. tamże 118 heth 9, CSEL 22, 427-428.

${ }^{38}$ Por. tamże 21, CSEL 22, 17.

${ }^{39}$ Por. tamże 118 heth 9, CSEL 22, 427-428.

${ }^{40}$ Por. tenże, De Trinitate II 22, CCL 62, 57-58, PSP 64, 91-92; tamże VIII 4, CCL 62A, 316317, PSP 64, 236-237.

${ }^{41}$ Por. tamże V 20, CCL 62, 170-172, PSP 64, 154-155; tamże VI 9, CCL 62, 203-205, PSP 64, 
fides $^{42}$, przeciwstawiająca się wierze heretyków, kłamliwej i uderzającej w prawdy wyznawane przez Kościół. Hilary zwraca uwagę na niewzruszoną pewność wiary, umacniającą i dodającą odwagę w trudach codzienności oraz na nadzieję wiary (fides spei) ${ }^{43}$, motywującą i zagrzewającą do zmagań wewnętrznych, która daje obietnicę nagrody za trwanie przy Bogu ${ }^{44}$.

Istotnym elementem w nauczaniu Hilarego jest stosunek wiary do poznania. Zagadnienie to ściśle wiąże się z kryteriami prawdziwej wiary. Wypływa również z potrzeby rozwoju intelektualnego wierzących wystawionych na ataki szalejącej w czasach Biskupa herezji. Hilary uznaje za konieczne, by człowiek nie tylko wierzył w Boga, ale też dążył do zrozumienia Boskich tajemnic. Wprowadza jednocześnie rozróżnienie pomiędzy wiarą i rozumem: „Wiara i wiedza - jak pisze - bardzo różnią się od siebie" ${ }^{45}$, chociaż w pewien sposób są ze sobą powiązane. Nieumiejętność poznania spraw przekraczających rozum nie zwalnia $\mathrm{z}$ wiary, ponieważ tylko ona zna prawdy niepoznawalne ${ }^{46}$. Wiara „wznosi się ponad ludzkie rozumienie" ${ }^{47}$, wykracza poza doświadczenie zmysłowe ${ }^{48}$. Wiara nie sprzeciwia się poznaniu, a jeśli tak się dzieje, przybiera postać niereligijną i nazywana jest przez Biskupa zbrodnią ${ }^{49}$. Zauważa on, że poznanie pod pewnym względem jest ważniejsze niż wiara: „Wiara bowiem ma zasługę posłuszeństwa, lecz nie ma ufności poznania prawdy" ${ }^{50}$.

Hilary nie ogranicza się jednak do wykazania związku wiary i rozumu, ale stara się znaleźć dla nich miejsce w szeregu łask. Jego zdaniem wiara stoi na trzecim miejscu, zaraz po mądrości i poznaniu ${ }^{51}$. Ważna jest zatem nie tylko wiara, ale i rozum. Biskup z Poitiers podkreśla, że nie wystarczy jedynie ufać Bożym obietnicom, lecz należy również dążyć do zrozumienia istoty Boga, by życie duchowe chrześcijanina rozwijało się prawidłowo. Obydwa te elementy - wiara i rozum - powinny zatem być obecne w życiu codziennym człowieka

171-172; tamże VI 36, CCL 62, 239-241, PSP 64, 190-191; tamże VIII 18, CCL 62A, 329-330, PSP 64, 243; tamże IX 28, CCL 62A, 401-402, PSP 64, 285; tenże, Commentarius in Matthaeum XIII 2, SCh 254, 296, PSP 63, 114; tenże, Tractatus super Ps. 118 lamed 11, CSEL 22, 463; tamże 67, 5, CSEL 22, 279-280.

${ }^{42}$ Por. tenże, Tractatus super Ps. 67, 1, CSEL 22, 276; tenże, Commentarius in Matthaeum IV 17, SCh 254, 134-136, PSP 63, 60; tamże IX 3, SCh 254, 206, PSP 63, 85; tamże XX 9, SCh 258, 112; tamże XXI 1, SCh 258, 120-122, PSP 63, 152-153.

${ }^{43}$ Por. tenże, Tractatus super Ps. 125, 9, CSEL 22, 610-611.

${ }^{44}$ Por. tenże, Commentarius in Matthaeum X 29, SCh 254, 250-252, PSP 63, 98.

${ }^{45}$ Tenże, Tractatus super Ps. 118 jod 12, CSEL 22, 446: „Distinxit apostolus plurimum inter cognitionem fidemque differe".

${ }^{46}$ Por. tenże, De Trinitate II 11, CCL 62, 48-49, PSP 64, 87.

${ }^{47}$ Tamże VI 36, CCL 62, 239-241, PSP 64, 190.

${ }^{48}$ Por. tamże IX 18, CCL 62A, 388-389, PSP 64, 278.

${ }^{49}$ Por. tamże VII 22, CCL 62, 284-286, PSP 64, 217.

${ }^{50}$ Tenże, Tractatus super Ps. 118 jod 12, CSEL 22, 446: „fides habet oboedientiae meritum, non habet autem cognitae veritatis fiduciam".

${ }^{51}$ Por. tamże 118 jod 12, CSEL 22, 446. 
i prowadzić go do zażyłości z Bogiem ${ }^{52}$. Można więc śmiało powiedzieć, że Biskup pisze o rozumnej wierze. Nie tylko opowiada się za możliwością postępu w rozumieniu wiary ${ }^{53}$, lecz także tworzy teorię rozumienia wiary (cognitio $^{54}$, doctrina ${ }^{55}$, scientia ${ }^{56}$, intelligentia ${ }^{57}$, intellectus ${ }^{58}$ ). Co ważne, rozumna wiara ściśle związana jest z pojmowaniem i interpretacją Pisma Świętego ${ }^{59}$. Odwołując się do słów biblijnych: „,szczęśliwy, kto mądrość (intelligentia) osiagną̧" (Prz 2,13), Hilary podkreśla wielką wartość rozumu i jego znaczenie dla wiary ${ }^{60}$. Zdaniem Biskupa poza zdobywaniem pokory, skromności, pobożności, powściągliwości i bojaźni przede wszystkim trzeba uczyć się wiary ${ }^{61}$. Przez tę naukę Bóg wiedzie wierzących po stopniach ku wzniosłym sprawom $^{62}$. Przez wiarę istota ludzka jest kształcona w duchowej wiedzy. Dzięki rozumnej wierze człowiek może dojrzeć Boga i zrozumieć Jego słowa ${ }^{63}$.

Bywa jednak, że wiara jest nieużyteczna w życiu duchowym i codzienności człowieka. Biskup z Poitiers na negatywnych przykładach uczy, jaka wiara nie może być uznana za doskonałą i godną poznania Boga. Wskazuje na chwiejną wiarę, która jego zdaniem stanowi wielkie niebezpieczeństwo dla życia wewnętrznego i zbawienia wierzących. Zdaniem Hilarego chwiejna wiara prowadzi do niewiary. Ci, którzy nie starają się o rozumną i doskonałą wiarę, „raczej sami sobie stwarzają wiarę niż ją przyjmują" ${ }^{64}$. Ważne jest, by wszystko było poddane Bogu; dopiero wtedy wiara jest stała i pewna, gdy nie dopuszcza fałszu i dwuznaczności do życia chrześcijanina. Hilary przestrzega, by:

„przypadkiem nasza wiara nie okazała się odmienną w odczuwaniu, a inną w słowach skutkiem obcości między zasięgiem serca i ust"65.

${ }^{52}$ Por. tamże 122, 12, CSEL 22, 588; tamże 134, 27, CSEL 22, 711-712. Zob. Fiedrowicz, Teologia ojców Kościoła, s. 44.

${ }^{53}$ Por. Hilarius Pictaviensis, Commentarius in Matthaeum XIII 2, SCh 254, 296, PSP 63, 114.

${ }^{54}$ Por. np. tenże, Tractatus super Ps. 52, 1, CSEL 22, 118; tamże 65, 1, CSEL 22, 248-249; tamże 125, 3, CSEL 22, 606-607; tenże, De Trinitate VI 28, CCL 62, 229-230; tenże, Commentarius in Matthaeum IV 11, SCh 254, 128-130, PSP 63, 58.

${ }^{55}$ Por. np. tenże, Tractatus super Ps. 53, 1, CSEL 22, 135; tamże 63, 6, CSEL 22, 227-229; tamże 118 aleph 5, CSEL 22, 361-362; tenże, De Trinitate VI 4, CCL 62, 198-199, PSP 64, 168.

${ }^{56}$ Por. np. tenże, Tractatus super Ps. 118 aleph 1, CSEL 22, 358-359; tamże 118 heth 19, CSEL 22, 433-434; tamże 130 5, CSEL 22, 659; tenże, De Trinitate VI 16, CCL 62, 214-215, PSP 64, 177.

${ }^{57}$ Por. np. tenże, Tractatus super Ps. 59, 1, CSEL 22, 191-193; tamże 91, 4, CSEL 22, 347-348; tamże 134, 1, CSEL 22, 693-695.

${ }^{58}$ Por. np. tamże 54, 1, CSEL 22, 147; tamże 118 he 6, CSEL 22, 403-404; tenże, Commentarius in Matthaeum XII 12, SCh 254, 278, PSP 63, 108.

${ }^{59}$ Por. tenże, Tractatus super Ps. 118 phe 4, CSEL 22, 508-509.

${ }^{60}$ Por. Fiedrowicz, Teologia ojców Kościoła, s. 44.

${ }^{61}$ Por. Hilarius Pictaviensis, Tractatus super Ps. 118, 3, CSEL 22, 356; tamże 118 aleph 8, CSEL 22, 363-364; tamże 118 jod 18, CSEL 22, 449-450; tamże 118 ain 1, CSEL 22, 495-496.

${ }^{62}$ Por. tamże 131, 1, CSEL 22, 660-661.

${ }^{63}$ Por. tamże 13, 5, CSEL 22, 82-83; tamże 52, 21, CSEL 22, 133-134.

${ }^{64}$ Tenże, De Trinitate VIII 1, CCL 62A, 311-313, PSP 64, 233-234.

${ }^{65}$ Tamże X 70, CCL 62A, 525-526, PSP 64, 357. 
Dodaje też, że wiara:

„powinna być zjednoczona tak z ustami, jak i z sercem, mając niepodważalną pobożność zarówno w odczuciu, jak i w mowie" ${ }^{" 66}$.

Słowa i uczynki, a nawet to, co jest w sercu człowieka, musi zgadzać się $\mathrm{z}$ wyznawaną wiarą. $\mathrm{W}$ ten sposób wierzący unika niebezpieczeństwa herezji i okazji do zgorszenia innych. Niepewna i chwiejna wiara właściwa jest raczej niby-sługom Boga, którzy ulegają podmuchom niepewności ${ }^{67}$. Jak Biskup zauważa, taki człowiek

„okazuje się sługą tylko z nazwy, jest chwiejny, na polu wiary ulega rozmaitym podmuchom niepewności, myśl jego i wola błąka się wśród wspomnień grzechów i wśród trosk i zachcianek"68.

Kto nie ma wiary, wszystkie przykazania Boże spełnia kłamliwie i pozornie ${ }^{69}$, szuka chwały nie u Boga, lecz u innych ludzi ${ }^{70}$, ułatwiając dostęp złym duchom do swego życia. Ludzie o chwiejnej wierze

„mają fałszywy pogląd na temat troski o rzeczy przyszłe i stawiają złośliwe pytania o wygląd ciał zmartwychwstałych i o jakość pokarmu w życiu wiecznym; i szukają w trudnościach bezużytecznych pytań uzasadnienia dla oddawania się przyjemnościom doczesnym, cały czas pozostając $\mathrm{w}$ bezsensownym strachu ze względu na należny Bogu respekt" "71.

Hilary zwraca uwagę na jeszcze jeden negatywny aspekt chwiejnej wiary. Jego zdaniem, chwiejna wiara pogrąża $\mathrm{w}$ trwodze i lęku ${ }^{72}$, staje się ciężarem. Wskazuje on na pogan udręczonych troską niewiary ${ }^{73}$ i miotanych wszystkimi przeciwnościami świata ${ }^{74}$ oraz uczy, że tylko silna wiara usuwa lęk ${ }^{75}$. Bez wiary ludzie boją się tego, czego bać się nie trzeba. Żywią zabobonny strach przed cieniami ${ }^{76} . \mathrm{Z}$ powodu chwiejnej wiary przestraszają się i przerażają ${ }^{77}$. Najistotniejsze jednak dla Biskupa z Poitiers jest to, że „najważniejsze dary tracą swoją wartość jako dary, o ile zabraknie wiary w Boga"78. Człowiek

${ }^{66}$ Tamże. Por. tenże, Tractatus super Ps. 14, 9, CSEL 22, 90-91.

${ }^{67}$ Por. tenże, Tractatus super Ps. 133, 2, CSEL 22, 691.

${ }^{68}$ Tamże 133, 2, CSEL 22, 691: „se servum nomine solo profiteatur, qui etiam nunc cunctabundus et fluctuans incerto fidei vento circumferatur, cujus cogitatio et voluntas in recordatione peccaminum, et in curas voluptatum evagetur".

${ }^{69}$ Por. tamże 53, 3, CSEL 22, 136.

${ }^{70}$ Por. tenże, De Trinitate IX 22, CCL 62A, 393-394, PSP 64, 281.

${ }^{71}$ Tenże, Commentarius in Matthaeum V 8, SCh 254, 156-158, PSP 63, 67.

${ }^{72}$ Por. tenże, De Trinitate VI 24, CCL 62, 223-224, PSP 64, 181.

${ }^{73}$ Por. tenże, Commentarius in Matthaeum V 12, SCh 254, 162-164, PSP 63, 69.

${ }^{74}$ Por. tamże XIV 14, SCh 258, 28, PSP 63, 122.

${ }^{75}$ Por. tenże, De Trinitate X 45, CCL 62A, 498-499, PSP 64, 341.

${ }^{76}$ Por. tenże, Tractatus super Ps. 52, 14, CSEL 22, 127-128.

${ }^{77}$ Por. tenże, Commentarius in Matthaeum XXX 3, SCh 258, 224, PSP 63, 185.

${ }^{78}$ Tenże, De Trinitate VIII 34, CCL 62A, 346-348, PSP 64, 253. 
o słabej i chwiejnej wierze pozbywa się wszystkiego, co otrzymał od Stwórcy i sam w niepewności zmaga się z trudami dnia codziennego. Hilary zauważa, że pod wpływem chwiejnej wiary:

„odmawiając Panu godności i współudziału w naturze Boga Ojca, przygotowują w różnorodnych dociekaniach herezje, stają się nijakimi - ani poganami, którzy działają w bezgrzesznej niewiedzy, ani też nie żyją wśród ludzi wyznających prawdę"

Chwiejna wiara zatem zgodnie z myślą Hilariańską prowadzi do herezji, ponieważ z powodu niewiary zamyka się dostęp światła do rozumu ${ }^{80}$. Dlatego Biskup pokazuje, że niewiarę płynącą z herezji należy zwalczać jedynie prawdziwą i doskonałą wiarą.

2. Prawdziwa wiara $\mathbf{w}$ walce $\mathbf{z}$ herezją. Hilary pisał na temat wiary nie tylko z troski o wiernych, lecz także by odeprzeć zarzuty kierowane przez arian. Walka z herezją w nauczaniu Biskupa stanowi jedno z głównych zagadnień. Przyglądając się jego dziełom, można stwierdzić, że udział w tej walce ma brać każdy, kto uznał Chrystusa jako swojego Pana. W tym celu Biskup pragnie wskazać wierzącym właściwą drogę wiary oraz sposoby zwalczania z jej pomocą herezji i niewiary. Zdaje on sobie sprawę, że każdy wierzący w swojej codzienności spotka się z atakami czy to ze strony pogan, czy też heretyków. Jak zauważa:

„Słusznie przez nas wyznawaną prawdziwą wiarę w Boga wyśmiewa filozofia, napastuje wściekłość heretyków, potępia zachłanne skapstwo, niepokoi gonitwa za godnościami. By na to wszystko być obojętnym, by to znieść, by tego uniknąć, by na to odpowiedzieć, umysł nasz - jeśli nie jest przez Boga wykształcony - nie jest zdolny"

Tylko doskonała i stała wiara:

„rozprawia się ze stwierdzeniami bezbożnego szaleństwa, zwalczając właśnie to, co zostało przeciwko niej skierowane" ${ }^{\text {, }}$,

przeciwstawia się przewrotności ${ }^{83}$ i osłabia zamysły spiskujących ${ }^{84}$. Powinna być zwrócona przeciwko błędnemu nauczaniu i bezbożności, stanowiącym

${ }^{79}$ Tenże, Commentarius in Matthaeum XII 18, SCh 254, 284-287, PSP 63, 110.

${ }^{80}$ Tenże, Tractatus Mysteriorum I 33, ed. J.P. Brisson, SCh 19bis, Paris 1967, 128, thum. E. Stanula: Św. Hilary z Poitiers, Komentarz do Ewangelii św. Mateusza. Traktat o Tajemnicach, PSP 63, 221.

${ }^{81}$ Tenże, Tractatus super PS. 63, 5, CSEL 22, 226-227: „per nos fidelem et veram confessionem nunc philosophia irrideat, nunc haereticorum furor incurset, nunc avaritiae studia condemnent, nunc ambitionis favor inquietet. Quibus omnibus dissimulandis, tolerandis, vitandis et coarguendis, mens nostra nisi per Deum erudita non sufficit".

${ }^{82}$ Tenże, De Trinitate IX 28, CCL 62A, 401-402, PSP 64, 285.

${ }^{83}$ Por. tamże IX 43, CCL 62A, 419-420, PSP 64, 295.

${ }^{84}$ Por. tenże, Tractatus super Ps. 63, 11, CSEL 22, 231-232. 
duże niebezpieczeństwo dla wierzących, ponieważ heretycy działają przede wszystkim wśród zniechęconych ${ }^{85}$. Hilary zauważa, że ludzi odznaczających się prawdziwą i doskonałą wiarą nienawidzą bezbożni. Człowiek, który wyznaje zarówno słowem, jak i całym swoim życiem, że przynależy do Boga, jest obrzydliwy dla szatana i jego sług. Walczą oni, by wierzącego pozbawić wia$\mathrm{ry}^{86}$. Każdy zaś zamiar przyjęcia wiary podcinają poprzez namawianie do żądz i pragnień ziemskich. By zapobiec odejściu od Boga, Biskup wskazuje na konieczność walki w obronie wiary ${ }^{87}$. Walka ta jest w myśli Hilariańskiej wpisana w codzienne życie wierzącego, jest ona wręcz niezbędna do dalszego wzrostu duchowego. Odwołując się do obrazów wziętych z życia, działających na wyobraźnię człowieka, Hilary podkreśla pozytywny aspekt zmagań z heretykami:

„Za łaską Ducha Świętego wreszcie dobijamy do spokojnego i bezpiecznego portu wiary. Często tak przytrafia się miotanym wichrami na szerokim morzu, że tuż przy wejściu do portu nieraz napotykają przygody albo powstrzymują ich wysokie fale, aż wreszcie napór straszliwych i zdradliwych bałwanów niejako wtłacza ich do znajomego i zacisznego schronienia. Żywię też nadzieję, że podobnie ma się rzecz z nami usiłującymi walczyć przeciwko heretyckiej nawałnicy [...]. Kiedy bowiem na najgorszy napór nawałnicy bezbożności wystawiamy mocny tył okrętu, same fale wpychają nas do upragnionego spokoju zatoki”"

Heretycy zatem, choć usiłują szkodzić, nie mogą zwyciężyć wierzących, chyba że zerwali dobrowolnie przyjaźń z Bogiem ${ }^{89}$. Silna zatem wiara odnosi zwycięstwo dzięki swojej stałości oraz pozbawia wroga wiary jego oręża, wiernością i miłością pokonuje nienawiśćc ${ }^{90}$. Dzięki poznaniu Boga płynącemu z wiary, zostaje odrzucona trucizna herezji ${ }^{11}$. Hilary, zwracając się do wierzących zauważa, że wielu próbuje podbić w niewolę wolność wiary, jednak nad wiarą nikt nie może panować ${ }^{22}$, a głoszony heretycki fałsz nie zdoła obalić prawdy ${ }^{93}$.

Biskup z Poitiers zwraca uwagę na jeszcze inny bardzo ważny aspekt walki z herezją:

„,wiara katolicka nie tylko skutecznie zwalcza poszczególne schorzenia, lecz jest także skutecznym środkiem zaradczym przeciw wszystkim chorobom. Nie osłabi jej rodzaj wrogów, nie pokona ich liczba, nie sfałszuje jej ich

\footnotetext{
${ }^{85}$ Por. tamże 118 ain 6, CSEL 22, 498.

${ }^{86}$ Por. tamże 118 lamed 13, CSEL 22, 464-465.

${ }^{87}$ Por. tamże 65, 13, CSEL 22, 257-258.

${ }^{88}$ Tenże, De Trinitate XII 1, CCL 62A, 579, PSP 64, 387.

${ }^{89}$ Por. tenże, Tractatus super Ps. 118 ain 6, CSEL 22, 498.

${ }^{90}$ Por. tamże 118 ain 2, CSEL 22, 496.

${ }^{91}$ Tenże, Commentarius in Matthaeum IX 9, SCh 254, 212-214, PSP 63, 87.

${ }^{92}$ Por. tenże, Tractatus super Ps. 124, 7, CSEL 22, 602-603.

${ }^{93}$ Por. tamże 63, 9, CSEL 22, 230-231.
} 
rozmaitość. Jedna i ta sama odpiera skutecznie wszelkie ich napaści, a więc każdej z osobna i wszystkim razem"94.

Odwołując się do terminologii medycznej, Hilary wskazuje na wiarę jako remedium na herezje jako schorzenie. Stanowi ona silne i skuteczne lekarstwo na rozmaite przypadłości duchowe. Co ważniejsze, zapobiega wszelkim chorobom niesionym przez przewrotne nauczanie bezbożnych. Hilary wykazuje troskę nie tylko o wierzących, lecz również o przeciwników nauczania Kościoła. Objawia się ona w traktowaniu herezji jako choroby, która może być uzdrowiona przez ewangeliczną wiarę. Wiara stanowi lekarstwo nie tylko na przypadłości napierające $\mathrm{z}$ zewnątrz, lecz również działa w duszy człowieka, lecząc go z duchowych słabości. Zdaniem Biskupa oświeca ona naturalne ciemności istoty ludzkiej ${ }^{95}$, ukazując drogę do Boga. Wiara również doprowadza grzeszników do światła poznania Boga ${ }^{96}$. Otwiera i rozszerza serce na przyjęcie nauki Bożej; sprawia, że człowiek staje się mieszkaniem i własnością Boga ${ }^{97}$. Cokolwiek człowiek cierpi ze strony heretyków, przeminie dzięki silnej wierze. Trudy zmagań i obrona wiary zapewnią natomiast wierzącemu zwycięstwo i nagrodę ${ }^{98}$.

3. Próba wiary. Zagadnienie codziennych zmagań oraz walki z atakami heretyków prowadzi do innego, również bardzo ważnego aspektu doskonałej wiary. Trudy dnia codziennego, napaści bezbożnych, prześladowania, niepowodzenia życiowe, choroby i cierpienie, które spotykają wierzącego, mogą złamać go i doprowadzić do utraty wiary, a w konsekwencji do odejścia od przyjaźni z Bogiem. Hilary zauważa, że wszystko co spotyka człowieka w jego życiu może jednak stanowić próbę wiary. W swoim nauczaniu Hilary nastawiony jest na przekazywanie wiedzy praktycznej ${ }^{99}$, skupia się przede wszystkim na roli doświadczeń dla wiary człowieka. Co ważne, wiara musi być poddawana próbie. Nie jest to wybór człowieka, ani jedna z dróg, którymi wierzący dochodzi do poznania Boga. Biskup wie, że próby są dla istoty ludzkiej ciężkim doświadczeniem i stanowią dla niej duże obciążenie ${ }^{100}$, dlatego w swoim nauczaniu pokazuje przede wszystkim pozytywny aspekt doświadczeń, które nazywa próbą czy też szkołą wiary.

W Traktacie na temat Psalmów Hilary jednoznacznie stwierdza: ,poprzez znoszenia cierpień, próbie zostaje poddana wiara"101. W życiu codziennym

\footnotetext{
${ }^{94}$ Tenże, De Trinitate II 22, CCL 62, 57-58, PSP 64, 91.

${ }_{95}$ Por. tenże, Tractatus super Ps. 118 phe 4, CSEL 22, 508-509.

${ }^{96}$ Por. tamże 59, 3, CSEL 22, 194-195.

${ }^{97}$ Por. tamże 118 daleth 12, CSEL 22, 397-398; tamże 118 phe 5, CSEL 22, 509-510.

${ }^{98}$ Por. tamże 124, 7, CSEL 22, 602-603.

${ }^{99}$ Por. tamże 118 beth 1-2, CSEL 22, 369-371.

${ }^{100}$ Por. tamże 118 caph 9, CSEL 22, 455-456.

${ }^{101}$ Tamże 118 samech 8, CSEL 22, 492: „per passionum patientiam fides probatur”.
} 
człowiek musi dać wiele dowodów żywej i prawdziwej wiary ${ }^{102}$. Zdaniem Biskupa, człowiek już w momencie przyjmowania wiary poddawany jest próbie, ponieważ musi przyjać i uznać śmierć Jezusa na krzyżu, którą niewierzący uznają zarówno za hańbę, jak i głupotę ${ }^{103}$. Przyjąwszy zaś wiarę, człowiek powinien uznać, że cokolwiek względem niego Bóg zarządzi jest dobre ${ }^{104}$. Powinien postępować tak jak Prorok, który wie, że:

„wyroki Boże są dobre. Albowiem Ten, który je wydał, jest Dobry. Wie, że cokolwiek nań przychodzi, przychodzi z wyroku Bożego"105.

Biskup, odpowiadając na wątpliwości wierzących wskazuje:

„Bóg zatem wystawia na próbę wierzących w Niego nie dlatego, jakby ich wiara była Mu nieznana; ale dlatego, że również, według Apostoła, pokusa jest próbą. Wierzący zatem są wystawiani na próbę nie po to, by Bogu dostarczyć wiadomości, lecz po to, by wybadali siebie; by oczyszczeni ogniem i uwolnieni z przymieszki grzechów cielesnych, jaśnieli blaskiem wypróbowanej niewinności"106.

Biskup wyraża przekonanie, że Bóg pragnie hartować wiarę człowieka w spotykających go smutkach, bólu, stracie ${ }^{107}$, a cokolwiek On nakazuje jest słuszne i uzasadnione ${ }^{108}$. Hilary, pisząc o próbie wiary, wielokrotnie powołuje się na postać Hioba, który za przyzwoleniem Bożym został doświadczony przez szatana; twierdzi, że Stwórca „dał diabłu prawo kusić Hioba w granicach ludzkiej słabości"'109. Człowiek poddawany jest próbie za przyzwoleniem Boga ${ }^{110}$ i ma w Nim swojego sojusznika, ponieważ próba wiary jest nieodzownym elementem duchowego życia człowieka. Próba wiary potrzebna jest dla jej uodpornienia na ataki heretyków ${ }^{111}$. Biskup z Poitiers, powołując się na nauczanie Pawła Apostoła, podkreśla, że wiara nigdy nie jest doświadczana ponad to, co może człowiek unieść. Bóg zna miarę słabości istoty ludzkiej i jest przy niej w najtrudniejszych zmaganiach, w jej doświadczeniach. Hilary zauważa,

\footnotetext{
${ }^{102}$ Por. tamże 118 ain 11, CSEL 22, 501-502.

${ }^{103}$ Por. tenże, Tractatus Mysteriorum I 36, SCh 19bis, 132-134, PSP 63, 223.

${ }^{104}$ Por. tenże, Tractatus super Ps. 118 teth 3, CSEL 22, 435-436.

${ }^{105}$ Por. tamże 118 teth 5, CSEL 22, 436-437.

${ }^{106}$ Tamże 65, 20, CSEL 22, 261-262: „Deus itaque credentes in se non tamquam fidei eorum ignarus examinat: sed quia etiam secundum Apostolum tentatio probationem affert, examinantur credentes non ad cognitionem Dei, sed ad sui probationem: ut igne purgati, et ab admixtione vitiorum carnalium defaecati, splendeant examinatae innocentiae claritate". Por. tamże 51, 16, CSEL 22, 108-109; tamże 53, 3, CSEL 22, 136; tamże 67, 31, CSEL 22, 306-307.

${ }^{107}$ Por. tamże 119, 8, CSEL 22, 549.

${ }^{108}$ Por. tamże 118 zade 1 , CSEL 22, 515.

${ }^{109}$ Tamże 118 aleph 15, CSEL 22, 368-369: „secundum modum infirmatis humanae temptanti

${ }^{110}$ Por. tamże.

${ }^{111}$ Por. tamże 118 heth 13, CSEL 22, 430.
} ius relinquit". 
że celem szatana jest to, by człowiek uwierzył, że opuszczony przez Stwórcę w najtrudniejszych dla niego momentach, został sam i jest zdany wyłącznie na siebie. Zdaniem Hilarego doświadczany człowiek powinien zwracać się do Boga słowami Modlitwy Pańskiej, prosząc Go o pomoc i wsparcie ${ }^{112}$. Wołanie zaś człowieka stanowi także jego walkę z dręczącymi go pokusami ${ }^{113}$. W walce z pokusami wspiera człowieka także bojaźń Imienia Pana i wspomnienie Jego obecności ${ }^{114}$.

Tylko wiara jest w stanie utrzymać człowieka przy Bogu we wszystkich przeciwnościach. W czasie próby wierzący umacnia się tak, że pragnie bardziej Boga niż rzeczy ziemskich ${ }^{115}$. Lgnąc do Stwórcy w znoszonych trudach, wiara odnosi zwycięstwo ${ }^{116}$. W przeciwnościach daje odpowiedź i podpowiada, jak wierzący powinien się zachowywać i co mówić ${ }^{117}$. Dlatego należy dbać o wiarę, by przypadkiem nie zachwiała się i nie doprowadziła istoty ludzkiej do zguby. Hilary zauważa:

„niebezpieczny jest pokój dla wiary niczym nienękanej, a bezpieczna straż łatwo może wpaść w zasadzkę. Natomiast człowieka zaprawionego w walkach szybko nie dosięgną podstępy; dla zdobycia zwycięskiego wieńca trzeba chwalebnie walczyć" 118 .

Jak żołnierz po zwycięskiej walce otrzymuje nagrodę za męstwo i odwagę, tak wierzący otrzymuje nagrodę za zasługi wiary:

„Pewny jest on bowiem, że za zasługi jego wiary czeka go nagroda, której ani oko nie widziało, ani ucho nie słyszało, która w serce człowiecze nie wstapiła, a którą przygotował Bóg tym, którzy Go miłują w Jezusie Chrystusie"119.

Największą nagrodą dla wiary jest to, czego jeszcze człowiek nie zna ${ }^{120}$. Jest to nagroda niebiańska ${ }^{121}$, sięgająca wieczności ${ }^{122}$, czyli życie wieczne pozbawione chorób i współzawodnictwa ${ }^{123}$. Żeby zaś człowiek mógł cieszyć się nieskończonością z Bogiem, musi przygotować sobie tę nagrodę staraniami życia

${ }^{112}$ Por. tamże 118 aleph 15, CSEL 22, 368-369.

${ }^{113}$ Por. tamże 119, 9, CSEL 22, 549-550.

${ }^{114}$ Por. tamże 62, 9, CSEL 22, 221-222.

${ }^{115}$ Por. tamże 62, 3, CSEL 22, 217-218.

${ }^{116}$ Por. tamże 62, 4, CSEL 22, 218-219.

${ }^{117}$ Por. tenże, Commentarius in Matthaeum X 14, SCh 254, 232, PSP 63, 93.

${ }^{118}$ Tenże, Tractatus super Ps. 118 caph 8, CSEL 22, 455: „Periculosa namque otiosae fidei pax est, et faciles securis excubiis insidiae sunt. Bellis autem exercitatum virum non cito doli capient: et glorioso certamine opus est, ut corona victoriae deferatur".

119 Tamże 118 nun 20, CSEL 22, 486-487: „Certus scilicet ea fidei meritis reservari et in his retributionem eius esse, quae oculus non vidit, nec auris audivit, nec in cor hominis ascendit; quae praeparavit deus his, qui diligunt eum in Christo Iesu".

${ }^{120}$ Por. tenże, De Trinitate VIII 10, CCL 62A, 321-322, PSP 64, 239-240.

${ }^{121}$ Por. tenże, Commentarius in Matthaeum X 13, SCh 254, 230-232, PSP 63, 92-93.

${ }^{122}$ Por. tamże IV 25, SCh 254, 144-145, PSP 63, 63.

${ }^{123}$ Por. tenże, Tractatus super Ps. 91, 10, CSEL 22, 353. 
codziennego wypływającymi z wiary. Dlatego w nauczaniu Hilarego, obok próby wiary, tak ważny jest jej związek z uczynkami ${ }^{124}$.

4. Uczynki wiary. Biskup $\mathrm{w}$ swoim nauczaniu udowadnia, że wiara i uczynki są ze sobą ściśle związane. Z wiary wypływają najlepsze uczynki ${ }^{125}$. Warto podkreślić, że łączy on je ze sobą i pisze o uczynkach wiary. Bez nich bowiem nie można poznać Boga. Jednocześnie Hilary zauważa, że nie od razu poznanie to idzie za czynami ani czyn nie doprowadza do prawdziwego poznania $^{126}$. Wiara zatem jest koniecznym elementem codzienności człowieka. Bez niej bowiem wszystko, co człowiek robi, jeśli nawet jest dobre, na nic się nie przydaje. Biskup z Poitiers zauważa, że także wśród pogan i heretyków można napotkać przejawy życia niewinnego, sprawiedliwego oraz zachowania czystości i wstrzemięźliwości. To postępowanie nie przybliża jednak do świętości, jeśli nie jest podejmowane w Chrystusie. Wszystko to jest pozbawione wartości, ponieważ nie ma żadnego związku z prawdziwą wiarą ${ }^{127}$. Podobnie jest $\mathrm{z}$ wyznawaniem Chrystusa. Jest ono głoszeniem szumnych haseł, jeśli poglądy, słowa, jak i postępowanie, zawierają fałsz ${ }^{128}$. Biskup u takich ludzi widzi rozdźwięk pomiędzy wyznawaną wiarą a prowadzonym życiem. Podaje także ich charakterystykę. $Z$ powodu braku wiary nienawidzą tego, co mówią, ponieważ nie są w stanie wyznawanych słów poświadczyć życiem. Ludzie pozbawieni wiary czczą Boga, a ich serce jest od Niego daleko. Ustami nie odważają się wyrazić kompromitujących myśli, wewnątrz zaś chowają złość i gniew ${ }^{129}$. Podobnie jest z ludźmi, którzy charakteryzują się chwiejną i niepewną wiarą. Zajmują oni w Hilariańskim nauczaniu pośrednie miejsce pomiędzy pobożnymi a bezbożnymi:

„Mają coś w sobie z jednych i z drugich; nie można ich jednak zaliczyć ani do jednych ani do drugich, bo częściowo należą do obydwóch grup. Nie można ich zaliczyć do wierzących, bo w pewnej mierze zarażeni są niedowiarstwem; ale nie można ich uważać i za niewierzących, bo mają coś z wiary. Jakoż wielu trzyma bojaźń Boża w Kościele; lecz jednocześnie rozrywki światowe nęca ich do światowych występków"130.

\footnotetext{
${ }^{124}$ Por. tamże.

${ }^{125}$ Por. tamże 120, 11, CSEL 22, 566-567.

${ }^{126}$ Por. tamże 20, CSEL 22, 16-17.

${ }^{127}$ Por. tamże 14, 8, CSEL 22, 90.

${ }^{128}$ Por. tamże 14, 9, CSEL 22, 90-91.

${ }^{129}$ Por. tamże 52, 2, CSEL 22, 118-119.

${ }^{130}$ Tamże 1, 22, CSEL 22, 34-35: „Sunt enim aliqui inter impios piosque qui medii sint, ex utroque admixti, neutri tamen proprie, quia in id ipsum constiterint ex utroque: nec fidei admiscendi, quia sit illis aliquid infidelitatis insertum; nec infidelitati deputandi, quia aliquid habeant et fidei. Plures namque Dei metus in Ecclesia continet: sed eosdem tamen ad saecularia vitia saeculi blandimenta solicitant".
} 
Biskup zauważa, że choćby tacy nawet wierzyli, bez owoców wiary, czyli uczynków, będą wyrwani i odrzuceni od Boga jako ludzie niepożyteczni, skoro nie przynoszą owoców wiary ${ }^{131}$. Chociaż należą do Kościoła, nie zachowują jego przepisów. Takimi są skappy, pijacy, leniwi, ludzie skłonni do gniewu, zarozumiali, obłudni, kłamcy i złodzieje. Zdaniem Hilarego do wymienionych występków pcha ludzi popęd ich natury.

Chociaż jednak natura popycha człowieka na drogę bezbożności, to właśnie wiara - zdaniem Biskupa - go od niej odwodzi ${ }^{132}$. Konieczne jest zatem, by wyznawana wiara wiązała się z uczynkami i codziennym postępowaniem człowieka $^{133}$. Biskup z Poitiers uznaje to za najchwalebniejszą rzecz ${ }^{134}$. Hilary wyraźnie wskazuje, że nie może być rozbieżności pomiędzy poglądami i słowami ${ }^{135}$. „Przyjęcie wiary - jego zdaniem - to nie sprawa dyskusji, lecz pójścia za nią"136, nawet jeśli prowadzi to do utraty życia. Owocem wyznawania życiem wiary jest znoszenie prześladowań ${ }^{137}$, a niekiedy męczeństwo ${ }^{138}$. Potwierdzanie wiary swoim życiem codziennym jest naśladownictwem apostołów, którzy zawsze głosili Boga mimo prześladowań i różnych zagrożeń, a jednak świadczenia życiem o wierze nie zaprzestali ${ }^{139}$. Apostołowie dali wierze świadectwo przez swą męczeńską śmierć, dzięki niej zostali uświęceni ${ }^{140}$. Takie poświadczanie wiary życiem, według myśli Hilariańskiej, należało nie tylko do apostołów, lecz także jest obowiązkiem każdego wierzącego ${ }^{141}$.

Wprowadzanie wyznawanej wiary w czyn, zdaniem Biskupa, nie jest jednak „sztuką dla sztuki”, ale ma określony cel. Uczynki wiary przynoszą korzyść nie tylko dla samego wyznawcy, lecz także dla innych, czy to dla wierzących, czy też dla nieznających prawdziwego Boga heretyków i pogan. Biskup zauważa, że niewierzący pociaggani są do poznania Boga nie przez słowa wierzących, lecz przez ich czyny ${ }^{142}$. Umysły pogan otwierają się pod wpływem doświadczenia i obserwacji uczynków wiary, uwalniane są spod władzy złych duchów ${ }^{143}$. Uczynki wiary są zatem konieczne, aby ci, którzy nie wierzą:

\footnotetext{
${ }^{131}$ Por. tamże 51, 16, CSEL 22, 108-109.

${ }_{132}$ Por. tamże 1, 9, CSEL 22, 24-25.

${ }^{133}$ Por. tamże 14, 9, CSEL 22, 90-91.

${ }^{134}$ Por. tamże 118 sin 1, CSEL 22, 535-536.

${ }^{135}$ Por. tamże 118 aleph 12, CSEL 22, 366-367.

136 Tenże, Commentarius in Matthaeum VII 10, SCh 254, 188-190, PSP 63, 78.

${ }^{137}$ Por. tenże, Tractatus super Ps. 118 zade 9, CSEL 22, 520-521.

${ }^{138}$ Por. tenże, Commentarius in Matthaeum X 11, SCh 254, 228-230, PSP 63, 92; tenże, Tractatus super Ps. 52, 12, CSEL 22, 125-126.

${ }^{139}$ Por. tenże, Tractatus super Ps. 65, 19, CSEL 22, 261; tamże 65, 21, CSEL 22, 262.

${ }^{140}$ Por. tamże 65, 26, CSEL 22, 266-267; tamże 66, 8, CSEL 22, 275.

${ }^{141}$ Por. tamże 63, 5, CSEL 22, 226-227.

142 Por. tenże, Commentarius in Matthaeum XV 5, SCh 258, 38-40, PSP 63, 126.

${ }^{143}$ Por. tenże, Tractatus super Ps. 52, 20-21, CSEL 22, 132-134.
} 
„przekonali się na podstawie czynów o wiarygodności głoszonej prawdy, aby to, co w nim podstępem grzeszników zostało skrępowane, było uwolnione dzięki zrozumieniu ewangelicznej wolności"144.

Sami wierzący poprzez wyznawanie wiary w swoim życiu konfrontują to, co wyznają, ze swoją codziennością. Dzięki temu ich wiara nabiera formy praktycznej oraz staje się rozumna. Przez wyznawanie wiary człowiek oczyszcza się ze wszelkiego fałszu i dwuznaczności ${ }^{145}$; poprzez uczynki wiary okazuje swoją przynależność do Boga ${ }^{146}$. W końcu wytrwałe wyznawanie wiary w myśli Hilariańskiej jest dla człowieka najbardziej zbawienne ${ }^{147}$.

Wiara to główne zagadnienie poruszane przez Biskupa zarówno w walce $\mathrm{z}$ herezją, jak też w trosce o duchowy rozwój wierzących. Zdaniem Hilarego wiara jest uznaniem bóstwa Jezusa i właściwym pojmowaniem Trójcy Świętej. W codziennym życiu człowiek powinien odznaczać się prawdziwą i stałą wiara, zgodna z kryteriami, które podaje Hilary w swoich dziełach, a przede wszystkim z Bożym Objawieniem i nauczaniem Kościoła. Wiara nie sprzeciwia się poznaniu, chociaż jedno i drugie różni się od siebie. Biskup zauważa, że w każdej chwili trzeba dbać, by wiara się nie zachwiała, ponieważ chwiejna prowadzi do niewiary i herezji. Dzięki rozumnej wierze oraz kształceniu duchowemu człowiek odpiera zarzuty heretyków i pogan, które - zgodnie z Hilariańską myślą - mają także pozytywną rolę w jego duchowym rozwoju. Wiara jest lekarstwem na bezbożną naukę, uzdrawia także wewnętrzne ciemności wierzącego. By jednak mogła prowadzić do zjednoczenia z Bogiem musi być poddawana próbie, która służy przede wszystkim poznaniu samego siebie. Tylko w niebezpieczeństwach i cierpieniu może być hartowana. Wydając zaś owoce, czyli uczynki, umocniona wiara prowadzi człowieka do zbawienia.

\section{HILARY OF POITIERS CONCERNING FAITH IN HUMAN LIFE}

\section{(Summary)}

According to Hilary, faith is a recognition of the divinity of Jesus and a proper understanding of the Trinity. As understood by him, faith is important above all in the fight against heresy and in the daily life of the people. He teaches that faith is not opposed to knowledge, although they differ from each other. Rational faith and spiritual education repel the attacks of heretics and pagans. Faith is a remedy

\footnotetext{
${ }^{144}$ Tenże, Commentarius in Matthaeum XI 2, SCh 254, 252-254, PSP 63, 99.

${ }^{145}$ Por. tenże, Tractatus super Ps. 118 samech 6, CSEL 22, 490-491.

146 Por. tamże 52, 19, CSEL 22, 132.

${ }^{147}$ Por. tenże, Commentarius in Matthaeum XXVI 5, SCh 258, 198-200, PSP 63, 177; tenże, Tractatus super Ps. 60, 2, CSEL 22, 203-204; tamże 61, 5, CSEL 22, 212.
} 
against impious doctrine and it heals the inner darkness of the believer. For faith to lead to union with God it must be tempted, because temptation leads to selfdiscovery. Faith can be strengthened only in danger and suffering, and acts of faith lead the believer to salvation.

Key words: Hilary of Poitiers, Expositions of the Psalms, belief, unbelief, heretics.

Słowa kluczowe: Hilary z Poitiers, Traktat na temat Psalmów, wiara, niewiara, heretycy. 
